\title{
A non-genomic signaling pathway shut down by mating changes the estradiol-induced gene expression profile in the rat oviduct
}

\author{
Alexis Parada-Bustamante ${ }^{1,2}$, Pedro A Orihuela ${ }^{3,4}$, Mariana Ríos ${ }^{1,2}$, Catherina A Cuevas ${ }^{3}$, \\ Maria Lorena Oróstica ${ }^{3}$, Luis A Velásquez ${ }^{3,4}$, Manuel J Villalón ${ }^{1}$ and Horacio B Croxatto ${ }^{2,3,4}$ \\ ${ }^{1}$ Unidad de Reproducción y Desarrollo, Facultad de Ciencias Biológicas, Pontificia Universidad Católica de Chile, \\ 8331010 Santiago, Chile, ${ }^{2}$ Millennium Institute for Fundamental and Applied Biology, 7780272 Santiago, Chile, \\ ${ }^{3}$ Laboratorio de Inmunología de la Reproducción, Facultad de Química y Biología, Universidad de Santiago de Chile, \\ 9170022 Santiago, Chile and ${ }^{4}$ Centro para el Desarrollo de la Nanociencia y la Nanotecnología (CEDENNA), \\ 9170124 Santiago, Chile
}

Correspondence should be addressed to A Parada-Bustamante who is now at School of Medicine, Institute of Maternal and Child Research, University of Chile, Santa Rosa 1234, Segundo Piso, Casilla 226-3, Santiago, Chile; Email: aparadab@med.uchile.cl

\begin{abstract}
Estradiol $\left(E_{2}\right)$ accelerates oviductal egg transport through intraoviductal non-genomic pathways in unmated rats and through genomic pathways in mated rats. This shift in pathways has been designated as intracellular path shifting (IPS), and represents a novel and hitherto unrecognized effect of mating on the female reproductive tract. We had reported previously that IPS involves shutting down the $\mathrm{E}_{2}$ non-genomic pathway up- and downstream of 2-methoxyestradiol. Here, we evaluated whether IPS involves changes in the genomic pathway too. Using microarray analysis, we found that a common group of genes changed its expression in response to $E_{2}$ in unmated and mated rats, indicating that an $E_{2}$ genomic signaling pathway is present before and after mating; however, a group of genes decreased its expression only in mated rats and another group of genes increased its expression only in unmated rats. We evaluated the possibility that this difference is a consequence of an $E_{2}$ non-genomic signaling pathway present in unmated rats, but not in mated rats. Mating shuts down this $E_{2}$ non-genomic signaling pathway up- and downstream of cAMP production. The Star level is increased by $E_{2}$ in unmated rats, but not in mated rats. This is blocked by the antagonist of estrogen receptor ICI 182780 , the adenylyl cyclase inhibitor SQ 22536 , and the catechol-O-methyltransferase inhibitor, $O R$ 486. These results indicate that the $\mathrm{E}_{2}$-induced gene expression profile in the rat oviduct differs before and after mating, and this difference is probably mediated by an $E_{2}$ non-genomic signaling pathway operating on gene expression only in unmated rats.
\end{abstract}

Reproduction (2010) 139 631-644

\section{Introduction}

The oviduct provides an optimal microenvironment for fertilization and early embryo development (Jansen 1984) and delivers the embryo to the uterus at the right time for implantation (Croxatto 1996). Estradiol $\left(E_{2}\right)$ is one of the main regulators of these phenomena modifying expression and secretion of molecules, which assure fertilization and embryo viability (Buhi 2002, Bhatt et al. 2004). $E_{2}$ determines how long oocytes and/or embryos are retained in the oviduct (Forcelledo et al. 1986, Croxatto et al. 1991), possibly through its action on the activity of muscle and ciliated cells (Villalón \& Verdugo 1982, Priyadarsana et al. 2004, Ríos et al. 2007), which provide the driving force for oviductal egg transport (Croxatto 2002).

$E_{2}$ exerts its effects after binding to estrogen receptors (ERs) which belong to the nuclear receptor superfamily (Cheskis et al. 2007). The molecular mechanisms by which $E_{2}$ changes the response of target tissues can be through genomic and non-genomic actions. In the genomic actions, estrogens bind to ERs in the nucleus, inducing a conformational change, which results in the regulation of gene transcription. In addition, $E_{2}$ is able to activate rapid intracellular signaling pathways (kinase activation, CAMP, and $\mathrm{IP}_{3}$ increase). Since the latter actions are not blocked by inhibitors of transcription or translation, they have been defined as non-genomic actions (Bjornstrom \& Sjoberg 2005).

A single injection of $E_{2}$ to unmated or mated rats shortens oviductal transport of eggs from the normal $72-96 \mathrm{~h}$ to $<24 \mathrm{~h}$ (Ortiz et al. 1979). In the absence of mating, $E_{2}$ uses only intraoviductal non-genomic pathways to accelerate egg transport (Ríos et al. 1997, Orihuela \& Croxatto 2001, Orihuela et al. 2001). This non-genomic pathway involves a previous conversion of $E_{2}$ to methoxyestradiols (MEs) mediated by the enzyme catechol-O-methyltransferase 
(COMT; Parada-Bustamante et al. 2007), ER activation (Orihuela et al. 2003), and successive activation of the cAMP-protein kinase A (PKA) and phospholipase C-IP 3 signaling cascades (Orihuela et al. 2006).

After mating, a profound change occurs in the pathways utilized by $E_{2}$ to accelerate egg transport. Instead of using the non-genomic pathway (Orihuela et al. 2001), it uses genomic pathways (Ríos et al. 1997).

The change in pathways utilized by $E_{2}$ to accelerate egg transport, from non-genomic to genomic, has been designated as 'intracellular path shifting' (IPS). This IPS caused by mating is a novel example of functional plasticity in well-differentiated cells. Through the effect of protein kinase inhibitors and translation inhibitors on $E_{2}$-induced accelerated ovum transport, we demonstrated that among mating-associated signals, the mechanical sensory stimulation of the genital area and the presence of spermatozoa in the uterus are able to elicit IPS (Parada-Bustamante et al. 2003, PeñarrojaMatutano et al. 2007); however, the mechanisms by which these signals produce this effect have not been elucidated.

IPS involves, at least, shutdown of the $E_{2}$ non-genomic signaling pathway, up- and downstream of MEs production, since mating decreases COMT activity and $2 \mathrm{ME}$ does not accelerate ovum transport in mated rats (Parada-Bustamante et al. 2007); however, the possibility that IPS involves changes or alterations in the genomic signaling pathway, which is used by $E_{2}$ to accelerate ovum transport after mating, has not been evaluated. Previous reports indicate that $E_{2}$ is able to change the expression of different proteins in the rat oviduct (Mathieu et al. 1989, Hermoso et al. 1997, Pérez Martínez et al. 2006); however, to our knowledge, no studies have been performed to determine whether these responses are different before and after mating. Here, we compared the effect of $E_{2}$ on gene expression in the oviduct of unmated and mated rats. We found that $E_{2}$ increased the expression of a number of genes common to both conditions, which indicates the presence of a common genomic pathway in unmated and mated rats. Surprisingly, a group of genes decreased its expression in mated rats, but not in unmated rats, and another group of genes increased its expression in unmated rats, but not in mated rats. Therefore, we evaluated whether $E_{2}$ nongenomic signaling pathway, present only in unmated rats, is responsible for these differences.

\section{Results}

\section{Mating changes the transcript profile induced by $E_{2}$ in the oviduct}

A microarray analysis using oviductal samples of unmated and mated rats treated s.c. with $10 \mu \mathrm{g} \mathrm{E}_{2}$ or vehicle was performed to determine whether $E_{2}$ elicits different genomic effects before and after mating.
A Decreased expression

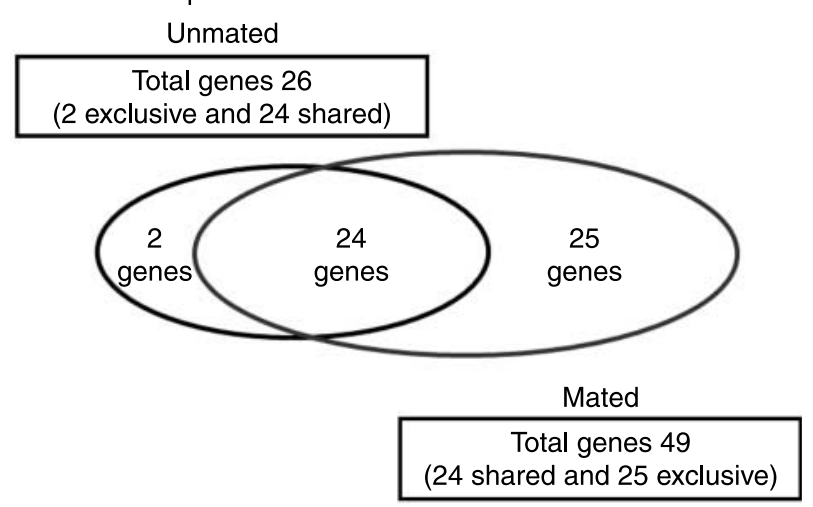

B Increased expression

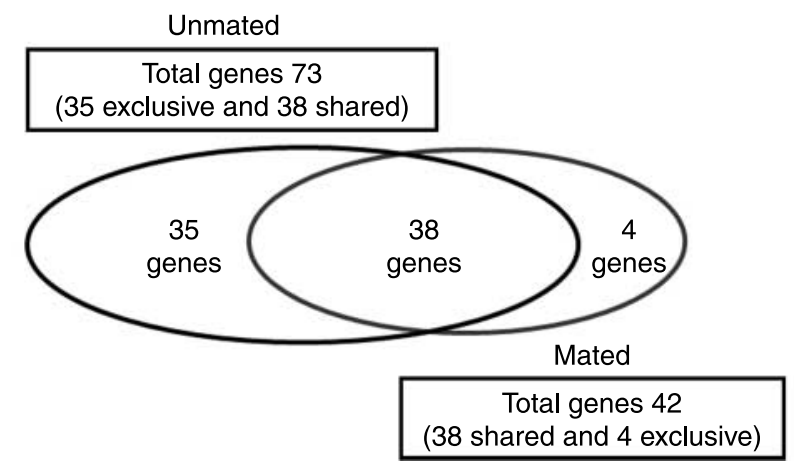

Figure 1 Changes in oviductal transcriptome induced by $E_{2}$ before (unmated) and after (mated) mating. Unmated $(N=10)$ or mated $(N=10)$ rats were injected s.c. with $E_{2}, 10 \mu \mathrm{g}$, or vehicle. Three hours later, oviducts were removed to extract their mRNA and perform a microarray analysis. The results obtained represent one affymetrix chip analysis per group performed with a RNA pool obtained from five animals. The number of transcripts that decreased (A) or increased (B) their expression in response to $E_{2}$ is shown separately.

Figure $1 \mathrm{~A}$ and $\mathrm{B}$ shows the genes that decreased or increased their expression in response to $E_{2}$ respectively. The transcript profile induced by $E_{2}$ was very different when this hormone was applied before or after mating. Before mating, $E_{2}$ decreased the expression of few genes, but increased the expression of a larger number of genes in comparison to the mated rats. A total of 26 known transcripts decreased their expression in response to $E_{2}$ before mating, whereas 49 did so after mating. The comparison of transcripts that decreased their level in both conditions indicated that only 2 decreased their expression exclusively in unmated rats, 25 decreased their expression only in mated rats, and 24 decreased their expression in both conditions (Fig. 1A). The complete lists of the corresponding genes are given in Tables 1-3.

A total of 73 known transcripts increased their expression in response to $E_{2}$ before mating, whereas only 42 did so after mating. The comparison of the genes that changed their expression in both conditions indicated that 35 increased their level exclusively in 
Table 1 Transcripts that decreased their level in the oviduct of unmated and mated rats $3 \mathrm{~h}$ after an estradiol $\left(\mathrm{E}_{2}\right), 10 \mu \mathrm{g}$, treatment.

\begin{tabular}{|c|c|c|c|c|c|}
\hline \multirow{2}{*}{$\begin{array}{l}\text { Probe set } \\
\text { ID affymetrix }\end{array}$} & \multirow[b]{2}{*}{ Accession number } & \multirow[b]{2}{*}{ Gene name } & \multirow{2}{*}{$\begin{array}{c}\text { Gene } \\
\text { symbol }\end{array}$} & \multicolumn{2}{|c|}{ Order of change } \\
\hline & & & & Unmated rats & Mated rats \\
\hline 1370019_at & NM_031834 & $\begin{array}{l}\text { Sulfotransferase family } 1 \mathrm{~A} \text {, phenol- } \\
\text { preferring, member } 1\end{array}$ & Sult1a1 & -2 & -2 \\
\hline 1368124_at & NM_133578 & Dual specificity phosphatase 5 & Dusp5 & -2 & -2 \\
\hline 1368894_at & NM_053874 & $\begin{array}{l}\text { CAP, adenylate cyclase-associated protein, } \\
2 \text { (yeast) }\end{array}$ & Cap2 & -2 & -2 \\
\hline 1368718_at & NM_017272 & $\begin{array}{l}\text { Aldehyde dehydrogenase family } 1, \\
\text { subfamily A7 }\end{array}$ & Aldh1a7 & -2 & -2 \\
\hline 1371883_at & NM_001007673 & $\begin{array}{l}\text { Monocyte to macrophage differentiation- } \\
\text { associated }\end{array}$ & Mmd & -2 & -2 \\
\hline 1368128_at & NM_031598 & $\begin{array}{l}\text { Phospholipase A2, group IIA (platelets, } \\
\text { synovial fluid) }\end{array}$ & Pla2g2a & -2 & -2 \\
\hline 1369670_at & NM_031518 & Cd200 antigen & $\mathrm{Cd} 200$ & -2 & -2 \\
\hline 1368911_at & NM_017099 & $\begin{array}{l}\text { Potassium inwardly rectifying channel, } \\
\text { subfamily J, member } 8\end{array}$ & Kcnj8 & -2 & -2.1 \\
\hline 1368869_at & NM_001033653 & A kinase (PRKA) anchor protein (gravin) 12 & Akap12 & -2 & -2.1 \\
\hline 1370310_at & NM_173094 & $\begin{array}{l}\text { 3-Hydroxy-3-methylglutaryl-coenzyme A } \\
\text { synthase } 2\end{array}$ & Hmgcs2 & -2 & -2.3 \\
\hline 1386908_at & NM_022278 & Glutaredoxin 1 (thioltransferase) & Glrx1 & -2 & -2.5 \\
\hline 1369113_at & NM_019282 & $\begin{array}{l}\text { Gremlin } 1 \text { homolog, cysteine knot } \\
\text { superfamily (Xenopus laevis) }\end{array}$ & Grem1 & -2 & -2.6 \\
\hline 1370228_at & NM_001013110 & Transferrin & $T f$ & -2.1 & -2 \\
\hline 1387658_at & NM_012947 & Eukaryotic elongation factor-2 kinase & Eef $2 k$ & -2.1 & -2 \\
\hline 1368870_at & NM_013060 & Inhibitor of DNA binding 2 & Id 2 & -2.1 & -2.1 \\
\hline 1367631_at & NM_022266 & Connective tissue growth factor & Ctgf & -2.1 & -3.5 \\
\hline 1368154_at & NM_017090 & Guanylate cyclase 1 , soluble, $\alpha 3$ & Gucy1a3 & -2.3 & -2.5 \\
\hline 1367859_at & NM_013174 & Transforming growth factor, $\beta 3$ & Tgfb3 & -2.3 & -2.6 \\
\hline 1387850_at & NM_023020 & $\begin{array}{l}\text { Transmembrane protein with EGF-like and } \\
\text { two follistatin-like domains } 1\end{array}$ & Tmeff2 & -2.3 & -4.9 \\
\hline 1387809_at & NM_053703 & MAP kinase kinase 6 & Map2k6 & -2.5 & -2.1 \\
\hline 1387074_at & NM_053453 & Regulator of G-protein signaling 2 & Rgs2 & -2.6 & -2.6 \\
\hline 1368168_at & NM_053380 & $\begin{array}{l}\text { Solute carrier family } 34 \text { (sodium phosphate), } \\
\text { member } 2\end{array}$ & Slc34a2 & -2.8 & -2 \\
\hline 1368025_at & NM_080906 & DNA-damage-inducible transcript 4 & Ddit4 & -2.8 & -2.8 \\
\hline 1371731_at & NM_001009617 & Mesoderm-specific transcript & Mest & -4 & -20 \\
\hline
\end{tabular}

unmated rats, only 4 did so exclusively in mated rats, and 38 increased their level in both conditions (Fig. 1B). The complete lists of the corresponding genes are given in Tables 4-6.

These results indicate that mating has a profound effect on the gene expression profile induced by $E_{2}$.

\section{$E_{2}$ activates a common genomic pathway in unmated and mated rats}

Thirty-eight transcripts increased their expression in unmated and mated rats in response to $E_{2}$ (Table 4), indicating that a common signaling pathway activated by $E_{2}$ is present before and after mating. The transcript encoding creatine kinase brain $(C k b)$ is one of them, and its increase was confirmed by real-time PCR (unmated rats: $51.6 \pm 8.4(N=5)$ versus $25.7 \pm 4.5$ $(N=5)$ in the control group and mated rats: $39.2 \pm 5.6$ $(N=5)$ versus $20.8 \pm 1.9(N=5)$ in the control group). Since this transcript is regulated by $\mathrm{E}_{2}$ in other organs by mechanisms that involve estrogen response elements (EREs) and Sp1 sites in its promoter (O'Lone et al. 2004), the common signaling pathway would involve, at least, a classical genomic pathway which requires binding of activated ER to these promoter regions.

\section{$E_{2}$ increases $C A M P$ level in the rat oviduct before, but not after, mating}

$E_{2}$ increases cAMP levels in the oviduct of unmated rats through a non-genomic signaling pathway (Orihuela et al. 2003). Here, we evaluated whether $E_{2}$ is able to

Table 2 Transcripts that decreased their level exclusively in the oviduct of unmated rats $3 \mathrm{~h}$ after an estradiol $\left(\mathrm{E}_{2}\right), 10 \mu \mathrm{g}$, treatment.

\begin{tabular}{lllcl}
\hline $\begin{array}{l}\text { Probe set } \\
\text { ID affymetrix }\end{array}$ & Accession number & Gene name & Gene symbol & $\begin{array}{c}\text { Order of change in } \\
\text { unmated rats }\end{array}$ \\
\hline 1370913_at & NM_138881 & $\begin{array}{c}\text { Radical S-adenosyl methionine domain } \\
\text { containing 2 } \\
\text { Nephrosis 1 homolog, nephrin (human) }\end{array}$ & Rsad2 & -2.1 \\
1369153_at & NM_022628 & Nphs & -9.8 \\
\hline
\end{tabular}


Table 3 Transcripts that decreased their level exclusively in the oviduct of mated rats $3 \mathrm{~h}$ after an estradiol $\left(\mathrm{E}_{2}\right), 10 \mu \mathrm{g}$, treatment.

\begin{tabular}{|c|c|c|c|c|}
\hline $\begin{array}{l}\text { Probe set ID } \\
\text { affymetrix }\end{array}$ & Accession number & Gene name & Gene symbol & $\begin{array}{l}\text { Order of change } \\
\text { in mated rats }\end{array}$ \\
\hline 1368771_at & NM_134378 & Sulfatase 1 & Sulf1 & -2 \\
\hline 1371179_a_at & XM_001077699 & $\begin{array}{l}\text { Fibroblast growth factor receptor } \\
2 \text { predicted }\end{array}$ & Fgfr2 & -2 \\
\hline 1387122_at & NM_012760 & Pleiomorphic adenoma gene-like 1 & Plag/1 & -2 \\
\hline 1370363_at & NM_133295 & Carboxylesterase 3 & Ces3 & -2.1 \\
\hline 1369526_at & NM_013084 & $\begin{array}{l}\text { Acyl-coenzyme A dehydrogenase, } \\
\text { short/branched chain }\end{array}$ & Acadsb & -2.3 \\
\hline 1368522_at & NM_031340 & Timeless homolog (Drosophila) & Timeless & -2.5 \\
\hline 1367598_at & NM_012681 & Transthyretin & Ttr & -2.5 \\
\hline 1387082_at & NM_053348 & Fetuin $\beta$ & Fetub & -2.6 \\
\hline 1368543_at & NM_053524 & NADPH oxidase 4 & Nox4 & -2.8 \\
\hline 1371083_at & NM_182474 & Serine protease inhibitor & LOC299282 & -3 \\
\hline 1368288_at & NM_012564 & Group-specific component & Gc & -3 \\
\hline 1368161_a_at & NM_012898 & $\alpha$-2-HS-glycoprotein & Ahsg & -3.5 \\
\hline 1368397_at & NM_001007264 & $\begin{array}{l}\text { UDP-glucuronosyltransferase } 2 \text { family, } \\
\text { member } 5\end{array}$ & Ugt2b5 & -3.5 \\
\hline 1387125_at & NM_053587 & $\begin{array}{l}\text { S100 calcium-binding protein A9 } \\
\text { (calgranulin B) }\end{array}$ & S100a9 & -3.5 \\
\hline 1370009_at & NM_012501 & Apolipoprotein C-III & Apoc3 & -3.7 \\
\hline 1370086_at & NM_012559 & Fibrinogen $\gamma$ polypeptide & Fgg & -3.7 \\
\hline 1369111_at & NM_012556 & Fatty acid-binding protein 1, liver & Fabp1 & -5.3 \\
\hline 1367896_at & NM_019292 & Carbonic anhydrase 3 & Ca3 & -6.1 \\
\hline 1368627_at & NM_031546 & Regucalcin & $\operatorname{Rgn}$ & -6.5 \\
\hline 1367555_at & NM_134326 & Albumin & Alb & -11.3 \\
\hline 1370396_x_at & NM_001034950 & Urinary protein 2 & Rup2 & -17.1 \\
\hline 1368733_at & NM_012883 & Sulfotransferase, estrogen preferring & Ste & -22.6 \\
\hline 1370593_at & NM_153312 & $\begin{array}{l}\text { Cytochrome P450, family } 3 \\
\text { subfamily a, polypeptide } 11\end{array}$ & Сур3а11 & -24.3 \\
\hline 1370349_a_at & XM_001056871 & $\begin{array}{l}\text { Similar to urinary protein } 3 \text { precursor } \\
\quad(\text { RUP-3) }\end{array}$ & LOC680367 & -24.3 \\
\hline 1368048_at & NM_012657 & $\begin{array}{l}\text { Serine (or cysteine) peptidase inhibitor, } \\
\text { clade A, member } 3 \mathrm{~K}\end{array}$ & Serpina3k & -27.9 \\
\hline
\end{tabular}

produce the same response after mating. In unmated rats, $\mathrm{E}_{2}$ increased cAMP levels almost twofold (2.76 $\pm 0.52 \mathrm{pmol} /$ oviduct $(N=3)$ versus $1.3 \pm 0.2 \mathrm{pmol} /$ oviduct $(N=3)$ in the control group) (Fig. 2), whereas in mated rats, $E_{2}$ did not change it $(1.3 \pm 0.2 \mathrm{pmol} /$ oviduct $(N=3)$ versus $1.2 \pm 0.35(N=3) \mathrm{pmol} /$ oviduct in the control group) (Fig. 2), indicating that mating shuts down an $E_{2}$ non-genomic signaling pathway in the oviduct, upstream of cAMP generation.

\section{Mating shuts down $E_{2}$ non-genomic signaling pathway downstream of cAMP generation}

Pharmacological treatments that increase cAMP production in the rat oviduct accelerate ovum transport in unmated rats (Orihuela et al. 2003). However, this effect has not been evaluated in mated rats. Twenty-four hours after treatment with forskolin, an average of $40 \%$ of oocytes left the oviduct prematurely in unmated rats $(6 \pm 0.8(N=5)$ versus $10.2 \pm 0.8(N=5)$ oviductal oocytes in the control group; Fig. $3 \mathrm{~A}$ ), whereas in mated rats, no effect was observed with this dose $(9.6 \pm 1.2(N=5)$ versus $10 \pm 1.8(N=5)$ oviductal embryos in the control group). To discard whether this effect of forskolin is only due to a differential activation of adenylyl cyclase isoforms in unmated and mated rats, the effect of $N^{6}, 2^{\prime}$-O-dibutyryladenosine $3^{\prime}, 5^{\prime}$-cyclic monophosphate sodium salt (dbcAMP), a cAMP analog, was evaluated. In unmated rats, $50 \%$ of the oocytes left the oviduct prematurely after treatment with $400 \mu \mathrm{g}$ of dbcAMP $(7 \pm 1.1(N=5)$ versus $11.6 \pm 0.8(N=5)$ in the control group; Fig. $3 \mathrm{~B}$ ), whereas the same dose had no effect on the number of oviductal embryos in mated rats $(8.6 \pm 1.0(N=5)$ versus $9.2 \pm 1.2(N=5)$ in the control group; Fig. $3 \mathrm{~B})$, indicating that mating shuts down an $\mathrm{E}_{2}$ non-genomic signaling pathway used by $E_{2}$ to accelerate ovum transport, downstream of cAMP generation too.

\section{$E_{2}$-induced non-genomic signaling pathway produces changes in gene expression in unmated rats, and mating shuts down this pathway: the case of STAR expression}

$E_{2}$ increased the level of 35 transcripts exclusively in unmated rats, suggesting that a signaling pathway activated by $E_{2}$ present before, but not after, mating is responsible for this effect. To characterize this response, a temporal course of Star expression, one of the transcripts that increased its expression in response to $E_{2}$ only in unmated rats, at RNA and protein levels was performed after $\mathrm{E}_{2}$ treatment.

In unmated rats, $\mathrm{E}_{2}$ significantly increased Star mRNA only $4.5 \mathrm{~h}$ after $\mathrm{E}_{2}$ treatment $(61.2 \pm 15.2$ vs $22.2 \pm 6.1$ 
Table 4 Transcripts that increased their level in the oviduct of unmated and mated rats $3 \mathrm{~h}$ after an estradiol $\left(\mathrm{E}_{2}\right), 10 \mu \mathrm{g}$, treatment.

\begin{tabular}{|c|c|c|c|c|c|}
\hline \multirow{2}{*}{$\begin{array}{l}\text { Probe set ID } \\
\text { affymetrix }\end{array}$} & \multirow[b]{2}{*}{ Accession number } & \multirow[b]{2}{*}{ Gene name } & \multirow[b]{2}{*}{ Gene symbol } & \multicolumn{2}{|c|}{ Order of change } \\
\hline & & & & Unmated rats & Mated rats \\
\hline 1367894_at & XM_001066529 & $\begin{array}{l}\text { Similar to insulin-induced gene } 1 \\
\text { protein (INSIG-1) }\end{array}$ & LOC688922 & +2 & +2 \\
\hline 1368685_at & NM_031022 & Chondroitin sulfate proteoglycan 4 & Cspg 4 & +2 & +2 \\
\hline 1387184_at & NM_024355 & Axin2 & Axin2 & +2 & +2.1 \\
\hline 1368542_at & NM_053583 & Zinc finger protein 423 & Zfp423 & +2 & +2 \\
\hline 1368272_at & NM_012571 & Glutamate oxaloacetate transaminase 1 & Got1 & +2 & +3 \\
\hline 1367802_at & NM_019232 & Serum/glucocorticoid-regulated kinase & $S g k$ & +2 & +2.3 \\
\hline 1370032_at & NM_021594 & $\begin{array}{l}\text { Solute carrier family } 9 \text { (sodium/ } \\
\text { hydrogen exchanger), isoform } \\
3 \text { regulator } 18\end{array}$ & Slc9a3r1 & +2 & +2.8 \\
\hline 1368465_at & NM_012892 & $\begin{array}{l}\text { Amiloride-sensitive cation channel } 1, \\
\text { neuronal (degenerin) }\end{array}$ & Accn1 & +2 & +2 \\
\hline 1387908_at & XM_001077321 & RAS, dexamethasone-induced 1 & Rasd1 & +2.1 & +2 \\
\hline 1387391_at & NM_080782 & Cyclin-dependent kinase inhibitor $1 \mathrm{~A}$ & $C d k n 1 a$ & +2.1 & +4.9 \\
\hline 1367740 at & M14400 & Creatine kinase, brain & $C k b$ & +2.1 & +2 \\
\hline 1369958_at & NM_022542 & Ras homolog gene family, member B & Rhob & +2.1 & +2 \\
\hline 1370074_at & XM_001055943 & Tensin & Tns & +2.1 & +2 \\
\hline 1370884_at & M36̄ 410 & Sepiapterin reductase & Spr & +2.1 & +2.1 \\
\hline 1387091_at & NM_017226 & Peptidyl arginine deiminase, type II & Padi2 & +2.1 & +2 \\
\hline 1370379_at & NM_138836 & Protease, serine, 8 (prostasin) & Prss8 & +2.1 & +2 \\
\hline 1388133_at & XM_345860 & $\begin{array}{l}\text { Cold shock domain containing C2, } \\
\text { RNA binding }\end{array}$ & Csdc2 & +2.1 & +2 \\
\hline 1368231_at & NM_017064 & Stat5A & Stat5a & +2.1 & +2 \\
\hline 1387332_at & NM_022275 & Neuromedin $\mathrm{U}$ receptor 2 & Nmur2 & +2.1 & +2.1 \\
\hline 1387010_s_at & NM_017288 & $\begin{array}{l}\text { Sodium channel, voltage-gated, } \\
\text { type I, } \beta\end{array}$ & Scn $1 b$ & +2.1 & +3.7 \\
\hline 1368826_at & NM_012531 & Catecholamine-O-methyltransferase & Comt & +2.1 & +2 \\
\hline 1368223_at & NM_024400 & $\begin{array}{l}\text { ADAM metallopeptidase with } \\
\text { thrombospondin type } 1 \text { motif, } 1\end{array}$ & Adamts1 & +2.3 & +2 \\
\hline 1369520_a_at & NM_017253 & $\begin{array}{l}\text { Branched chain aminotransferase 1, } \\
\text { cytosolic }\end{array}$ & Bcat1 & +2.3 & +2.3 \\
\hline 1387099_at & NM_053838 & Natriuretic peptide receptor 2 & Npr2 & +2.3 & +2 \\
\hline 1370173 at & NM_017051 & Superoxide dismutase 2 , mitochondrial & Sod2 & +2.3 & +2.1 \\
\hline 1387563_at & NM_022847 & Progesterone receptor & Pgr & +2.3 & +3.2 \\
\hline 1387737_at & NM_134351 & Methionine adenosyltransferase II & Mat2 & +2.3 & +2 \\
\hline 1387260_at & NM_053713 & Kruppel-like factor 4 (gut) & Klf4 & +2.5 & +2 \\
\hline 1370333_a_at & NM_178866 & Insulin-like growth factor 1 & Igf1 & +2.5 & +2 \\
\hline 1370225_at & NM_053699 & $\begin{array}{l}\text { Cbp/p300-interacting transactivator, } \\
\text { with Glu/Asp-rich carboxy-terminal } \\
\text { domain, } 4\end{array}$ & Cited4 & +2.6 & +2.3 \\
\hline 1367725_at & NM_022602 & Serine/threonine-protein kinase pim-3 & Pim 3 & +2.6 & +2 \\
\hline 1368283_at & NM_133606 & $\begin{array}{l}\text { Enoyl-coenzyme A, hydratase/ } \\
\text { 3-hydroxyacyl coenzyme A } \\
\text { dehydrogenase }\end{array}$ & Ehhadh & +2.6 & +2 \\
\hline 1369443_at & NM_133569 & Angiopoietin-like 2 & Angpt/2 & +3 & +2 \\
\hline 1370708_a_at & NM_138547 & $\begin{array}{l}\text { Aldo-keto reductase family } 1 \text {, member } \\
\text { C14 }\end{array}$ & Akr1c14 & +3 & +2.1 \\
\hline 1369798_at & NM_012507 & $\begin{array}{l}\text { ATPase, } \mathrm{Na}^{+} / \mathrm{K}^{+} \text {transporting, } \\
\quad \beta 2 \text { polypeptide }\end{array}$ & Atp1b2 & +4 & +2 \\
\hline 1368148_at & NM_012610 & $\begin{array}{l}\text { Nerve growth factor receptor (TNFR } \\
\text { superfamily, member 16) }\end{array}$ & Ngfr & +5.3 & +2 \\
\hline 1370517_at & NM_153735 & Neuronal pentraxin 1 & Nptx1 & +9.2 & +3 \\
\hline 1368102_at & NM_017081 & Hydroxysteroid $11 \beta$ dehydrogenase 2 & Hsd11b2 & +9.2 & +3.5 \\
\hline
\end{tabular}

group vehicle, Fig. 4, unmated), whereas its protein level was increased at all times studied, with maximal increases being reached 4.5 and $6 \mathrm{~h}$ after $\mathrm{E}_{2}$ treatment $(4.0 \pm 1.0$ and $4.5 \pm 1.2$ times respectively, Fig. 5, unmated). In mated rats, $E_{2}$ did not change mRNA (Fig. 4, mated) and protein (Fig. 5, mated) levels of STAR at any time studied.

Since mating shuts down $\mathrm{E}_{2}$-induced non-genomic signaling pathway up- and downstream of cAMP generation, the possibility that this pathway is responsible for transcript level changes induced by $E_{2}$ observed only in unmated rats was evaluated. For this, the $\mathrm{E}_{2}$-induced Star expression increase in unmated rats was studied by blocking the ER and cAMP production, which are the two key components that mediate $\mathrm{E}_{2}$ nongenomic signaling pathway (Orihuela et al. 2003). ICI 182 780, an ER antagonist, and SQ 22536, an adenylyl cyclase inhibitor, or their vehicles were administered 
Table 5 Transcripts that increased their level exclusively in the oviduct of unmated rats $3 \mathrm{~h}$ after an estradiol $\left(\mathrm{E}_{2}\right), 10 \mu \mathrm{g}$, treatment.

\begin{tabular}{|c|c|c|c|c|}
\hline $\begin{array}{l}\text { Probe set ID } \\
\text { affymetrix }\end{array}$ & Accession number & Gene name & $\begin{array}{l}\text { Gene } \\
\text { symbol }\end{array}$ & $\begin{array}{l}\text { Order of change } \\
\text { in unmated rats }\end{array}$ \\
\hline 1369554_at & NM_053553 & Synaptogyrin 2 & Syngr2 & +2 \\
\hline 1387629_at & NM_022261 & B-box and SPRY domain containing & Bspry & +2 \\
\hline 1370153_at & NM_019216 & Growth differentiation factor 15 & Gdf15 & +2 \\
\hline 1371059_at & NM_019264 & $\begin{array}{l}\text { Protein kinase, cAMP-dependent, regulatory, } \\
\text { type } 2 \alpha\end{array}$ & Prkar2a & +2 \\
\hline 1369177_at & NM_053735 & Phosphatidylinositol 4-kinase type $2 \alpha$ & Pi4k2a & +2 \\
\hline 1370212_at & NM_053310 & Homer homolog 3 (Drosophila) & Homer3 & +2 \\
\hline 1368845_at & NM_024000 & caM kinase-like vesicle-associated & Camkv & +2 \\
\hline 1368147_at & NM_053769 & Dual specificity phosphatase 1 & Dusp1 & +2 \\
\hline 1368449_at & NM_133567 & Centaurin $\alpha 1$ & Centa1 & +2 \\
\hline 1387894_at & NM_144730 & GATA binding protein 4 & Gata4 & +2 \\
\hline 1369012_at & NM_017128 & Inhibin $\beta-A$ & Inhba & +2 \\
\hline 1387353_at & NM_017093 & Thymoma viral proto-oncogene 2 & Akt2 & +2 \\
\hline 1387876_at & NM_022380 & Stat5B & Stat $5 b$ & +2.1 \\
\hline 1386909_a_at & NM_031353 & Voltage-dependent anion channel 1 & Vdac1 & +2.1 \\
\hline 1369650 at & NM 053306 & p21 (CDKN1A)-activated kinase 2 & Pak2 & +2.1 \\
\hline 1368931_at & NM_031238 & SH3-domain GRB2-like 3 & $\operatorname{Sh} 3 g / 3$ & +2.1 \\
\hline 1387133_at & NM_053988 & Calbindin 2 & Calb2 & +2.3 \\
\hline 1387844_at & NM_032613 & $\mathrm{LIM}$ and $\mathrm{SH} 3$ protein 1 & Lasp1 & +2.3 \\
\hline 1370780_at & NM_145094 & RAB31, member RAS oncogene family & Rab31 & +2.3 \\
\hline 1368884_at & NM_022587 & $\begin{array}{l}\text { Ectonucleoside triphosphate } \\
\text { diphosphohydrolase } 1\end{array}$ & Entpd1 & +2.3 \\
\hline 1369640_at & NM_012567 & Gap junction membrane channel protein $\alpha 1$ & Gja1 & +2.5 \\
\hline 1369278_at & NM_031034 & Guanine nucleotide binding protein, $\alpha 12$ & Gna12 & +2.5 \\
\hline 1383096_at & XM_343513 & Amyloid $\beta$ (A4) precursor-like protein 2 & Aplp2 & +2.5 \\
\hline 1387707_at & NM_017102 & $\begin{array}{l}\text { Solute carrier family } 2 \text { (facilitated glucose } \\
\text { transporter), member } 3\end{array}$ & Slc2a3 & +2.5 \\
\hline 1387810_at & NM_057152 & Kelch-like ECH-associated protein 1 & Keap1 & +2.5 \\
\hline 1370488_a_at & NM_019140 & $\begin{array}{l}\text { Protein tyrosine phosphatase, receptor } \\
\text { type, D }\end{array}$ & Ptprd & +2.6 \\
\hline 1387420_at & NM_031818 & Chloride intracellular channel 4 & Clic4 & +2.8 \\
\hline 1387858 at & NM_080907 & Protein phosphatase 4 , regulatory subunit 1 & Ppp4r1 & +2.8 \\
\hline 1370344_at & NM_153629 & Heat shock protein 4 & Hspa4 & +3 \\
\hline 1368406 at & NM 031558 & Star & Star & +3.2 \\
\hline 1370714_a_at & NM_147205 & $\beta$-Galactoside- $\alpha-2,6$ sialyltransferase 1 & St6gal1 & +3.2 \\
\hline 1369703_at & NM_023090 & Endothelial PAS domain protein 1 & Epas1 & +3.2 \\
\hline 1368897 at & NM_030858 & MAD homolog 7 (Drosophila) & Smad7 & +3.5 \\
\hline 1387833_at & NM_130424 & Transmembrane protease, serine 2 & Tmprss2 & +6.5 \\
\hline 1388249_at & XM_001079347 & $\begin{array}{l}\text { Rap guanine nucleotide exchange } \\
\text { factor (GEF) } 1\end{array}$ & Rapgef1 & +10.6 \\
\hline
\end{tabular}

intrabursally (i.b.) in unmated rats following a s.c. injection with $E_{2}$ or its vehicle. In rats receiving local treatment with vehicle, $E_{2}$ increased STAR levels (ICl experiment: $2.16 \pm 0.17(N=3)$, Fig. $6 \mathrm{~A}$, and SQ 22536 experiment: $1.81 \pm 0.01(N=3)$, Fig. $6 \mathrm{~B})$. ICI 182780 and SQ 22536 completely blocked the increase of STAR induced by $E_{2}(0.65 \pm 0.07 \quad(N=3)$ and $1.12 \pm 0.16$ $(N=3)$, Fig. $6 \mathrm{~A}$ and $\mathrm{B}$ respectively), whereas these drugs when applied alone did not affect STAR expression by themselves $(0.8 \pm 0.14(N=3)$ and $1.09 \pm 0.11$ $(N=3)$, Fig. 6A and $B$ respectively). These results indicate that increased STAR expression induced by $E_{2}$ in unmated rats requires an active ER and an increase of cAMP levels.

STAR immunoreactivity was detected only in epithelial cells of the ampulla and isthmus (Fig. 7), indicating that at least part of the pathway utilized by $E_{2}$ to increase STAR expression is present in this cell phenotype.

Altogether these data indicate that some, if not all, genes that increase their expression in the oviductal epithelium in response to $E_{2}$ exclusively in unmated rats do so, at least in part, in response to the activation of a

Table 6 Transcripts that increased their level exclusively in the oviduct of mated rats $3 \mathrm{~h}$ after an estradiol $\left(\mathrm{E}_{2}\right), 10 \mu \mathrm{g}$, treatment.

\begin{tabular}{|c|c|c|c|c|}
\hline $\begin{array}{l}\text { Probe set ID } \\
\text { affymetrix }\end{array}$ & Accession number & Gene name & Gene symbol & $\begin{array}{l}\text { Order of change } \\
\text { in mated rats }\end{array}$ \\
\hline 1368339_at & NM_012521 & S100 calcium-binding protein $G$ & S100g & +2.5 \\
\hline 1368342_at & NM_031544 & Adenosine monophosphate deaminase 3 & Ampd3 & +2.8 \\
\hline 1368290_at & NM_031327 & Cysteine-rich protein 61 & Cyr61 & +4 \\
\hline 1371193_at & XM_001065494 & Tumor necrosis factor $\alpha$-induced protein 6 & Tnfaip6 & +10 \\
\hline
\end{tabular}




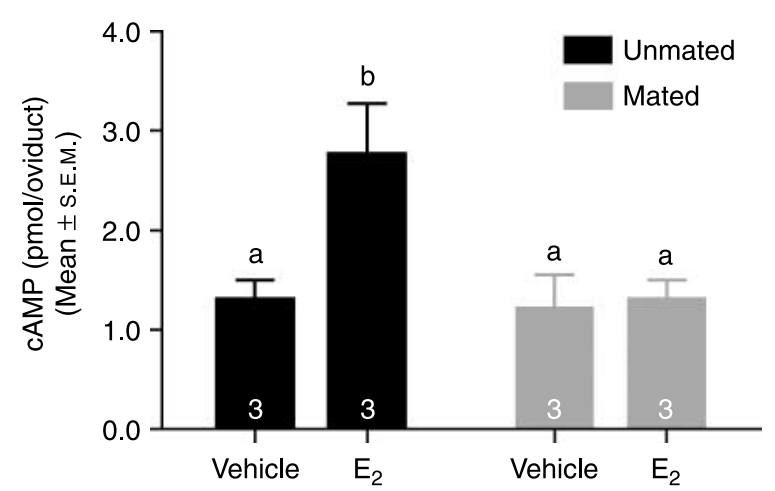

Figure 2 Effect of estradiol on oviductal cAMP level before (unmated) and after (mated) mating. cAMP level in the oviduct of unmated and mated rats $\left(N=3\right.$ animals by treatment) $3 \mathrm{~h}$ after a s.c. injection of $E_{2}$, $10 \mu \mathrm{g}$, or vehicle. Numbers inside the bars indicate the number of animals used. Means with different letters are significantly different from each other $(P<0.05)$.

local non-genomic signaling pathway that increases cAMP levels. Mating shuts down this pathway, preventing $E_{2}$ from increasing the expression of these genes in mated rats.

\section{$E_{2}$ regulated STAR expression, COMT requirement, and effect of $2 M E$}

Local formation of MEs mediated by COMT is essential for the intraoviductal non-genomic pathway utilized by $E_{2}$ to accelerate egg transport in unmated rats (Parada-Bustamante et al. 2007). Here, we evaluated whether OR 486, a COMT inhibitor, blocks the $\mathrm{E}_{2}$-induced increase in STAR levels. OR 486 or its vehicle was administered i.b. in unmated rats after a s.c. injection of $E_{2}$ or its vehicle. $E_{2}$ increased STAR levels significantly (2.3 \pm 0.6 times over control, Fig. 8$)$, and OR 486 completely blocked this effect $(1.1 \pm 0.2$ times over control, Fig. 8), whereas OR 486 alone had no effect $(1.2 \pm 0.3$ times over control). Moreover, STAR levels increased significantly 1.5 and $3 \mathrm{~h}$ after $2 \mathrm{ME}$ treatment $(2.4 \pm 0.6$ and $1.6 \pm 0.3$ times over control respectively, Fig. 9), indicating that local conversion of $E_{2}$ to $M E$ is an essential component of the non-genomic signaling pathway of $E_{2}$ that regulates STAR expression in the oviduct of unmated rats.

\section{Discussion}

Mating has a profound impact on oviductal physiology, changing the pathway by which $E_{2}$ accelerates ovum transport from non-genomic to genomic (IPS). In this study, the genomic pathways that respond to $E_{2}$ before and after mating were explored. We found that the $\mathrm{E}_{2}$-induced gene expression profile in the rat oviduct is different depending on whether the animal has mated or not. More genes were increased and fewer genes were decreased by $E_{2}$ before mating than after mating. Since more information about the mechanisms by which $E_{2}$ increases gene expression is present in the literature, our analysis was focused on the group of genes that were increased by $E_{2}$. The fact that 38 genes are increased in unmated and mated rats indicates that a common pathway that is able to increase gene expression is present before and after mating. According to the literature, some of these genes are regulated by $E_{2}$ in other rat organs such as angiopoietin 2 in the heart, kidney, and lung (Ye et al. 2004), hydroxysteroid $11 \beta$ dehydrogenase 2 in the kidney (Gómez-Sánchez et al. 2003), insulin-like growth factor 1 (Igf1) in the oviduct (Carlsson et al. 1993), progesterone receptor in the lung (González-Arenas et al. 2003), and Ckb in pituitary gland (Blake et al. 2005). Functional analysis of progesterone receptor promoter, which is one among this group of genes, indicated that it contained imperfect EREs, which are necessary for increasing its levels by $E_{2}$; moreover, $C k b$ promoter contains EREs and GC-rich sites, which are used by $E_{2}$, bound to $E R$, to increase its levels (Scott et al. 2003). In this work, we confirmed that $\mathrm{E}_{2}$ increased $C k b$ mRNA levels in unmated and mated rat
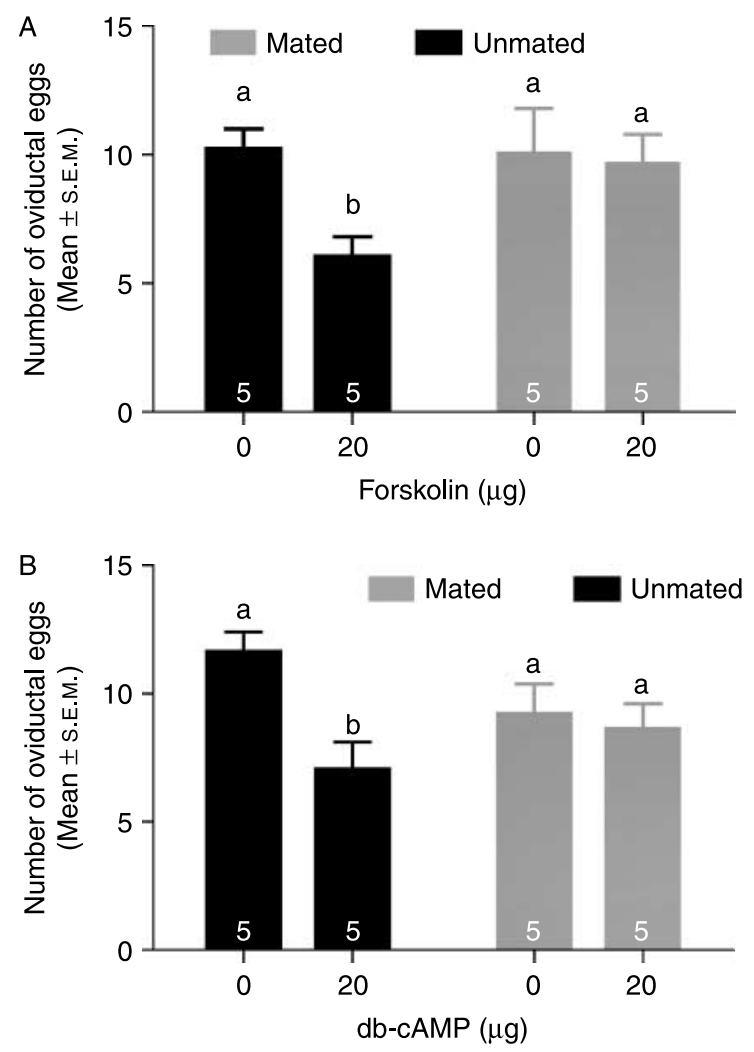

Figure 3 Forskolin and dibutyryl-cAMP accelerate ovum transport in unmated rats, but not in mated rats. Number of oocytes or embryos recovered from the oviduct of unmated and mated rats $(N=5$ animals by treatment) $24 \mathrm{~h}$ after being injected with forskolin, $20 \mu \mathrm{g}$, or vehicle i.b. (A) or with dbcAMP, 4 or $400 \mu \mathrm{g}$, or vehicle i.b. (B). Numbers inside the bars indicate the number of animals used. Means with different letters are significantly different from each other $(P<0.05)$. 

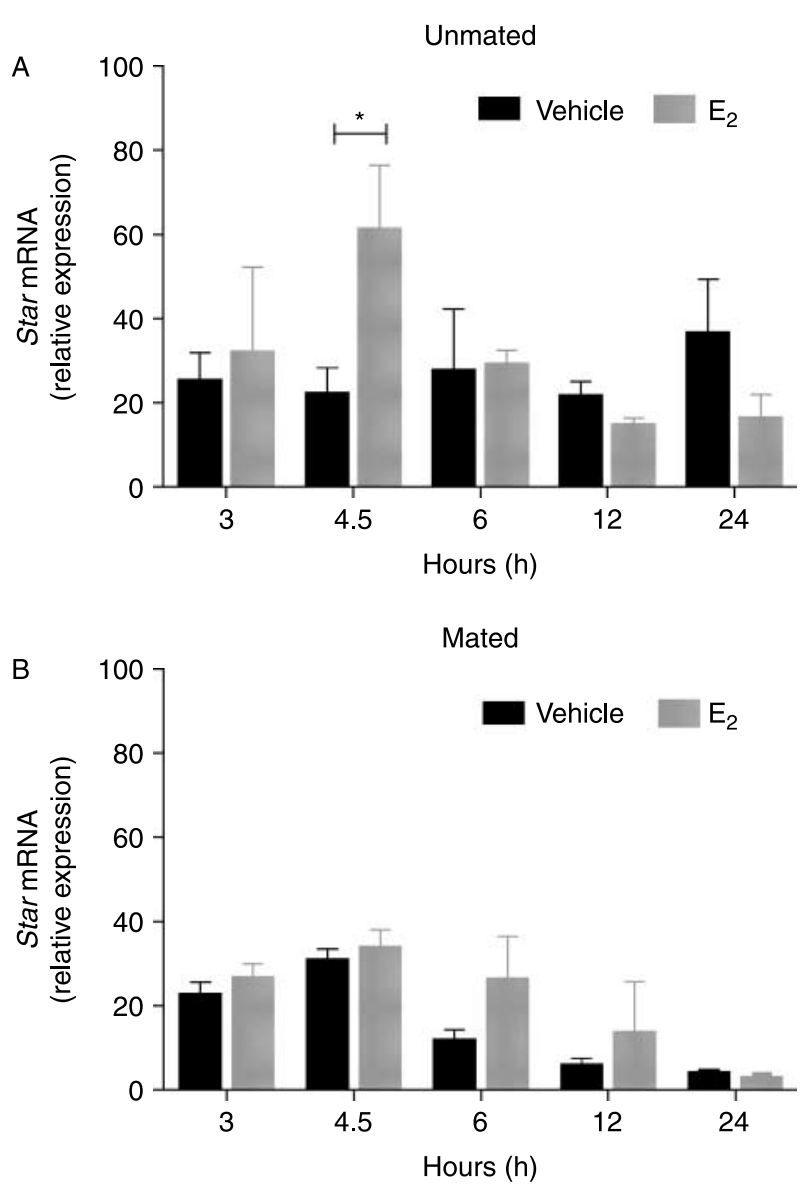

Figure 4 Estradiol increases oviductal Star mRNA levels in unmated rats, but not in mated rats. Star mRNA relative expression obtained through real-time PCR from cDNA of oviductal samples $(N=5$ animals by treatment) taken from unmated and mated rats $3,4.5,6,12$, and $24 \mathrm{~h}$ after a s.c. injection of $\mathrm{E}_{2}, 10 \mu \mathrm{g}$, or vehicle. The values were normalized to Gapdh. Each bar represents the mean value obtained from five animals. The asterisk indicates a statistically significant difference between the two bars at $4.5 \mathrm{~h}(P<0.05)$.

oviduct, indicating that the common pathway is, at least, a classical genomic pathway which is dependent on direct or indirect ER-DNA interaction.

$E_{2}$ increased the expression of some transcripts exclusively in unmated rats, but not in mated rats, indicating that a pathway that is able to increase the expression of these transcripts is present in unmated rats, whereas mating shut it down by unrecognized mechanisms. Previously, we had determined that in IPS, the $E_{2}$ non-genomic pathway is shut down up- and downstream of $2 \mathrm{ME}$ (Parada-Bustamante et al. 2007); here, we show that mating shuts down the non-genomic pathway up- and downstream of cAMP production. The fact that the $E_{2}$ non-genomic signaling pathway is shut down due to mating, and that some genes, such as inhibin B-A (Ardekani et al. 1998), Smad7 (Bilezikjian et al. 2001), gap junction protein, $\alpha 1$ (Abudara et al. 1999), and Star (Stocco et al. 2005), which increased their expression only in unmated rats are increased by
cAMP and PKA activation in other rat tissues, indicates that in unmated rats, $E_{2}$ increases the expression of these genes activating a non-genomic pathway. After mating, this pathway is shut down and then $E_{2}$ is unable to increase the expression level of this group of genes. In accordance with this idea, in unmated rats, Star mRNA levels are increased $4.5 \mathrm{~h}$ after $\mathrm{E}_{2}$ treatment, whereas in mated rats, Star mRNA levels did not change at any time point studied. Furthermore, the fact that increases of STAR protein induced by $E_{2}$ require $E R$ activation and CAMP production suggests that this effect is dependent on the intraoviductal $E_{2}$ non-genomic signaling. Since $\mathrm{ICl} 182780$ alone did not affect STAR expression, it is
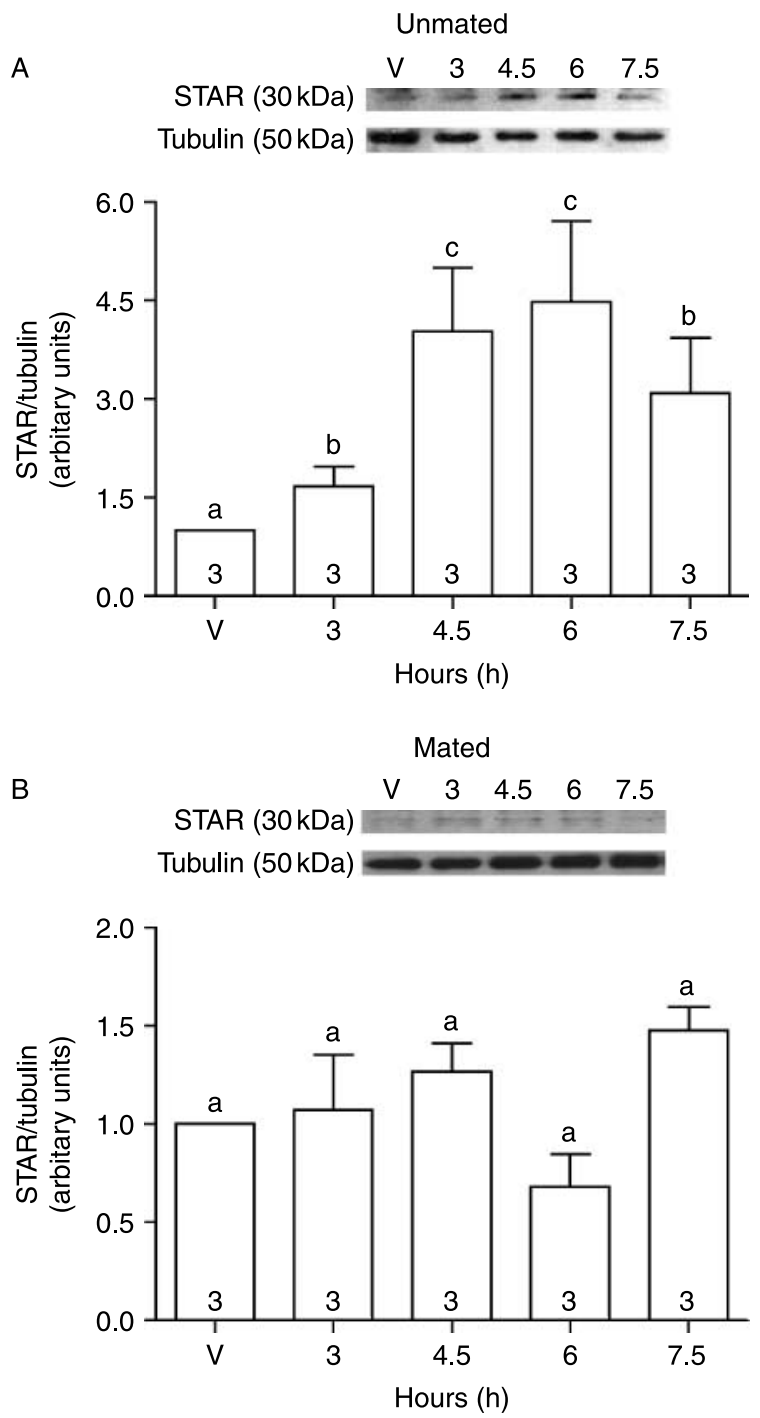

Figure 5 Estradiol increases oviductal STAR protein levels in unmated rats, but not in mated rats. Densitometric analysis of western blots to detect STAR protein in oviductal samples $(20 \mu \mathrm{g}, N=3$ animals by treatment) taken $3,4.5,6$, and $7.5 \mathrm{~h}$ after a s.c. injection of $\mathrm{E}_{2}, 10 \mu \mathrm{g}$, or vehicle. The values were normalized to $\alpha$-tubulin. A representative western blot obtained in this experiment is shown. Numbers inside the bars indicate the number of animals used. Means with different letters are significantly different from each other $(P<0.05)$. 
A
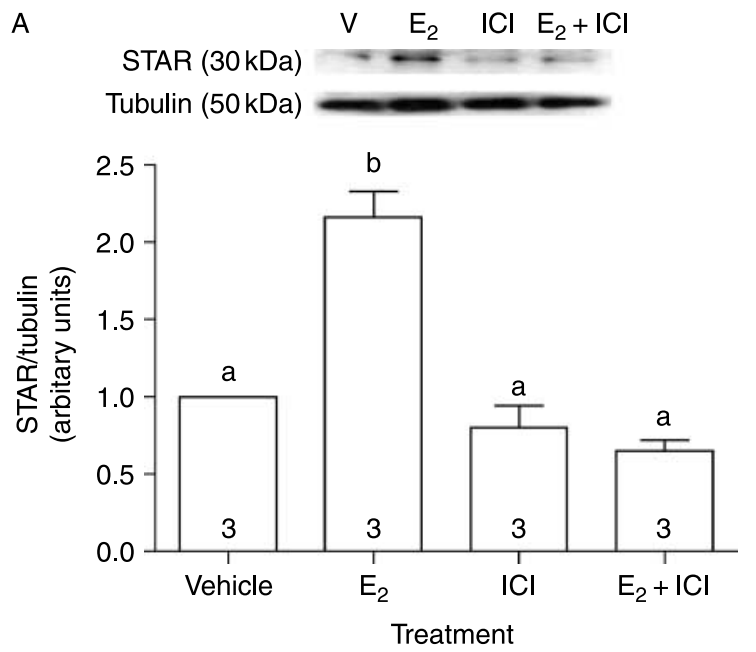

B
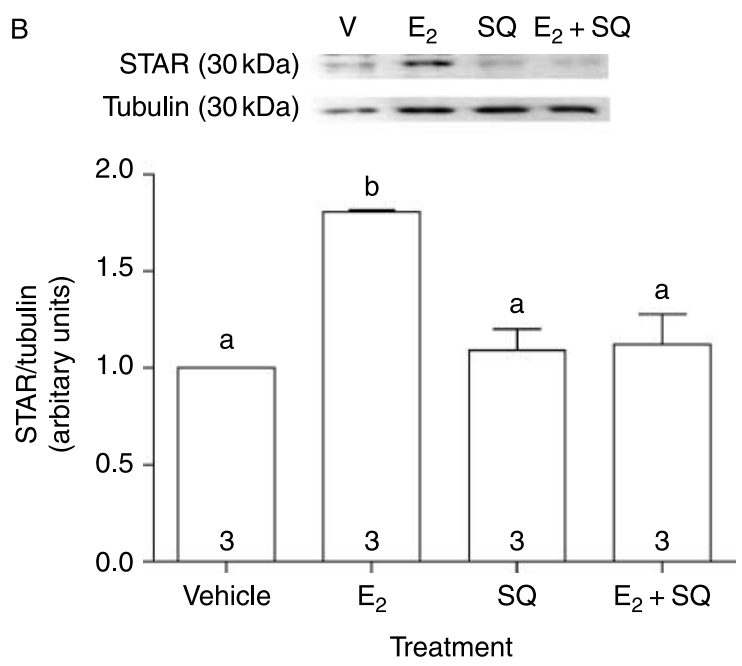

Figure 6 Increased expression of STAR levels in the oviduct in response to $E_{2}$ requires estrogen receptor and cAMP. Densitometric analysis of western blots to detect STAR protein in oviductal samples $(20 \mu \mathrm{g}, N=3$ animals by treatment) of unmated rats $4.5 \mathrm{~h}$ after injecting $\mathrm{E}_{2}, 10 \mu \mathrm{g}$, or vehicle s.c. and concomitantly the estrogen receptor antagonist, ICI 182780 (A), the adenylyl cyclase inhibitor, SQ 22536 (B), or their vehicle given i.b. The values were normalized to $\alpha$-tubulin. A representative western blot is shown. Numbers inside the bars indicate the number of animals used. Means with different letters are significantly different from each other $(P<0.05)$.

probable that other endogenous signaling pathways are acting to state basal STAR levels in the rat oviduct. In accordance with this idea, previous reports have determined that STAR expression is regulated by several signaling pathways and factors, such as IGF1, arachidonic acid, protein kinase C, and MAP kinases (reviewed in Stocco et al. (2005)).

The fact that Star mRNA levels were increased only in one of the points studied is in agreement with our previous results, which indicated that cAMP levels are increased $3 \mathrm{~h}$ after $E_{2}$ treatment, whereas its levels returned to basal levels at $6 \mathrm{~h}$ (P Orihuela 2006, unpublished observations). STAR protein levels were increased slightly, but significantly $3 \mathrm{~h}$ after $\mathrm{E}_{2}$ treatment, even though its mRNA levels were increased from $4.5 \mathrm{~h}$ onwards after treatment, probably because CAMP-PKA pathway activation increases STAR protein stability (Clark et al. 2001). This also indicates that STAR protein levels are maintained elevated until $7.5 \mathrm{~h}$ after $E_{2}$ treatment. In mated rats, $E_{2}$ did not change STAR protein levels at any time studied. These results indicate that $E_{2}$ increases STAR protein levels in unmated rats, activating a non-genomic pathway that requires $E_{2}$ receptor and adenylyl cyclase.

This shutdown of $E_{2}$ non-genomic signaling pathway in mated rats could be explained by differences in $E_{2}$ levels or changes in the expression or location of $E R$ induced by mating in the rat oviduct. However, previous reports have shown that plasma $E_{2}$ levels and oviductal ESR1 $(E R-\alpha)$ and ESR2 (ER- $\beta)$ mRNA and protein levels did not change in the initial hours after mating (Smith et al. 1975, Orihuela et al. 2004). Another possibility could be the interactions among ERs and proteins that mediate $E_{2}$ non-genomic signaling pathways in unmated rats, which do not occur in mated rats. For example, it has been found that PELP-1/MNAR is an ER-interacting protein (Brann et al. 2008) which is required for ESR1 interaction with p60 (SRC), which leads to the activation of SRC/MAPK pathway (reviewed in Cheskis et al. (2008)); however, this possible differential interaction in the rat oviduct was not evaluated in this work.

$E_{2}$ increased STAR levels only in the epithelial cells, indicating that $\mathrm{E}_{2}$-activated non-genomic pathway is present only in these cells. This is in agreement with our previous results using primary cell cultures from rat oviduct, where $E_{2}$ increased cAMP levels in epithelial cells, but not in muscle cells (P Orihuela 2007, unpublished observations); however, we do not discount that other components of the non-genomic pathway are present in other cell types, since IP3 levels are increased 1 and $6 \mathrm{~h}$ after $\mathrm{E}_{2}$ treatment in the whole rat oviduct (Orihuela et al. 2006).

CAMP regulates STAR expression in other tissues and organs through PKA activation and subsequent transcription factor phosphorylation such as GATA4 and CREB (Stocco et al. 2005). The effectors that are downstream of CAMP production, responsible for $E_{2}$-induced STAR increases in the rat oviduct, were not studied in this work. To our knowledge, this is the first time that STAR expression is reported in the oviduct, and that its expression is increased by $\mathrm{E}_{2}$; a previous work reported that STAR expression is decreased in interstitial and theca ovarian cells in newborn rats treated with $E_{2}$ benzoate (lkeda et al. 2001). STAR is a key protein in steroidogenesis, because it mediates cholesterol entry from external to internal mitochondrial membranes (Stocco \& Clark 1996). The function of STAR in the oviduct was not explored in this work; however, since $\mathrm{E}_{2}$-induced acceleration transport is not blocked by transcription and translation inhibitors in unmated rats, 

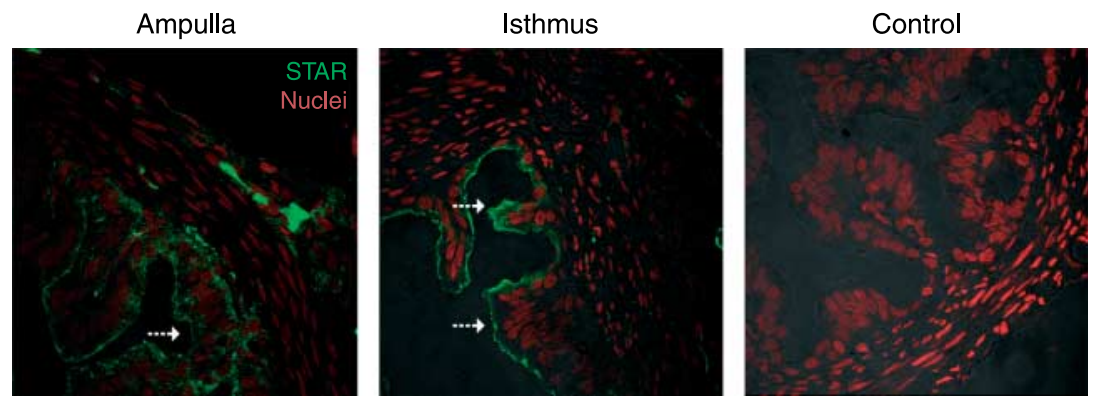

Figure 7 STAR is expressed in epithelial cells in unmated rat oviduct. Representative photomicrographs obtained from unmated rat oviducts $4.5 \mathrm{~h}$ after injecting $E_{2}, 10 \mu$ g, s.c. $(N=3)$ to detect STAR expression (green). Nuclei were stained with propidium iodide (red). Arrows point to immunoreactivity obtained only in the epithelial cells. The specificity of immunoreactivity was assessed by incubating samples with preimmune serum.

the increase of its expression would not mediate this phenomenon.

The $E_{2}$ non-genomic pathway in the oviduct involves conversion of $E_{2}$ to MEs mediated by COMT (Parada-Bustamante et al. 2007). In accordance with this, a COMT inhibitor blocked $E_{2}$-induced STAR increased expression and 2ME increased STAR protein expression. The fact that STAR levels were increased only $3 \mathrm{~h}$ after $2 \mathrm{ME}$ treatment, whereas they were increased 3, $4.5,6$, and $7.5 \mathrm{~h}$ after $\mathrm{E}_{2}$ treatment can be explained by a fast $2 \mathrm{ME}$ metabolization. cAMP levels are increased in the rat oviduct only $3 \mathrm{~h}$ after $\mathrm{E}_{2}$ treatment (Orihuela et al. 2006); this latency time can represent the time required by $E_{2}$ to be metabolized to $2 \mathrm{ME}$. We hypothetize that $2 \mathrm{ME}$ treatment would increase cAMP faster than $\mathrm{E}_{2}$, but this was not tested in this work.

The physiological relevance of preventing increased expression of a group of genes by $E_{2}$ in the rat oviduct by mating-associated signals was not explored in this work. We postulate that failure of the mechanism that is responsible for the shutdown of this pathway would affect normal embryo development. In order to corroborate this idea, it is necessary to prevent IPS and then to determine whether in this condition there are alterations in reproductive phenomena such as embryo development and implantation; however, this was not explored in this work.

In summary, these results indicate that $E_{2}$-induced gene expression profile in the rat oviduct differs before and after mating, and this difference is possibly mediated by the effects of $E_{2}$ non-genomic signaling pathway on gene expression operating only in unmated rats; the early events induced by mating responsible for this phenomenon are still unknown.

\section{Materials and Methods}

\section{Animals}

Locally bred Sprague-Dawley rats were used. The animals were kept under controlled temperature $\left(21-24^{\circ} \mathrm{C}\right)$, and lights were kept on from 0700 to $2100 \mathrm{~h}$. Water and pelleted rat chow were supplied ad libitum. Females weighing 200-220 g were selected from those that had at least two regular cycles of 4 days immediately before the experiments were started.
Daily vaginal smears, which were taken between 0800 and $0900 \mathrm{~h}$, were used to verify cycle regularity (Turner 1961). To obtain unmated and mated rats, females in the evening of proestrus were either kept isolated or caged with fertile males. The next morning, isolated rats that presented cornified cells in the vaginal smear, a cell phenotype associated with ovulation (estrus day), were designated as unmated rats, and those caged with fertile males that presented cornified cells and spermatozoa in the vaginal smear were designated as mated rats. The care and manipulation of the animals were carried out in accordance with the ethical guidelines of Pontificia Universidad Católica de Chile and Universidad de Santiago de Chile.

\section{Treatments}

All treatments described below were administered at $1200 \mathrm{~h}$ in unmated and mated rats.

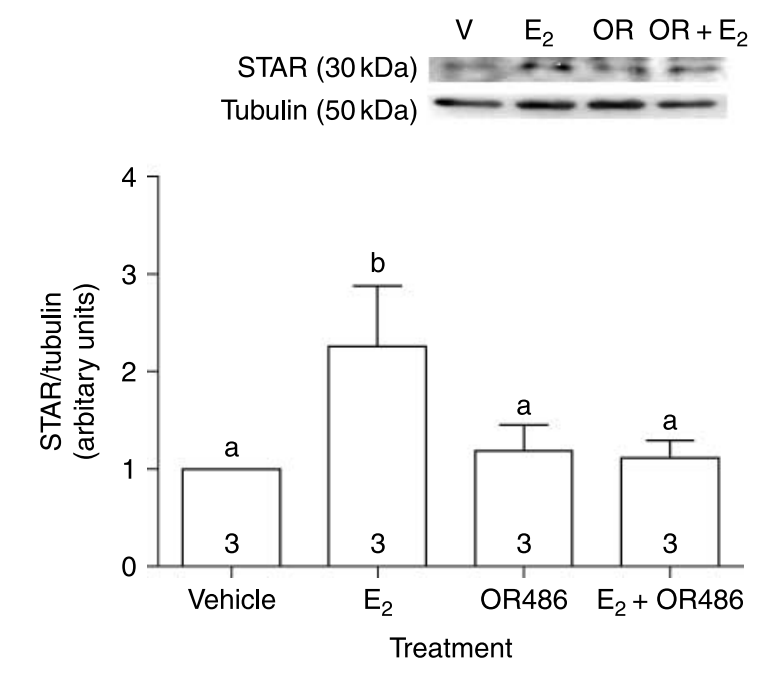

Figure 8 OR 486 blocks increased expression of STAR levels in the oviduct in response to $E_{2}$ in unmated rats. Densitometric analysis of western blots to detect STAR protein in oviductal samples $(20 \mu \mathrm{g}, \mathrm{N}=3$ animals by treatment) of unmated rats $4.5 \mathrm{~h}$ after injecting $\mathrm{E}_{2}, 10 \mu \mathrm{g}$, or vehicle s.c. and concomitantly the COMT inhibitor, OR 486, or vehicle given i.b. The values were normalized to $\alpha$-tubulin. A representative western blot is shown. Numbers inside the bars indicate the number of animals used. Means with different letters are significantly different from each other $(P<0.05)$. 


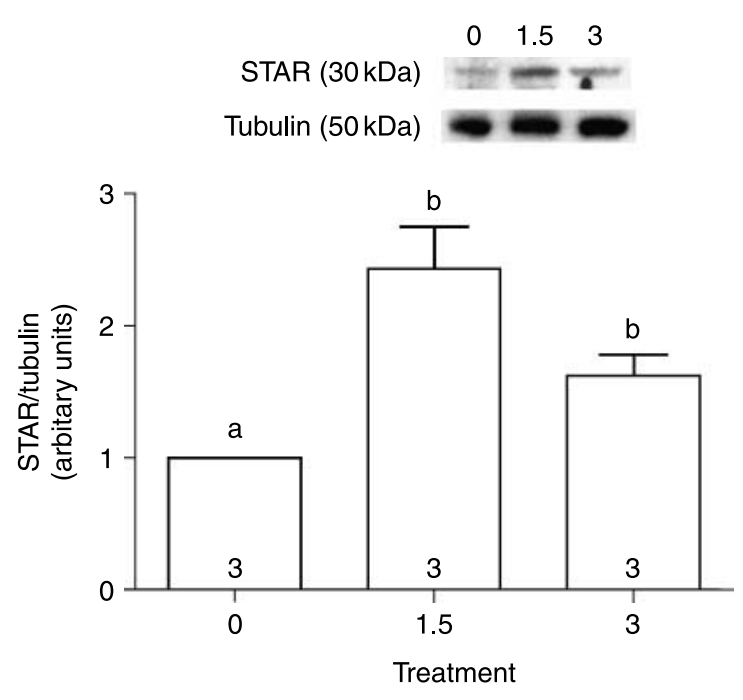

Figure 9 2-Methoxyestradiol increases oviductal STAR levels in unmated rats. Densitometric analysis of western blots to detect STAR protein in oviductal samples $(20 \mu \mathrm{g}, \mathrm{N}=3$ animals by treatment) from unmated rats taken 1.5 and $3 \mathrm{~h}$ after a s.c. injection of 2-methoxyestradiol, $100 \mu \mathrm{g}$, or vehicle. The values were normalized to $\alpha$-tubulin. A representative western blot is shown. Numbers inside the bars indicate the number of animals used. Means with different letters are significantly different from each other $(P<0.05)$.

\section{Systemic administration of $E_{2}$ or $2 M E$}

Unmated and mated rats were injected s.c. with $10 \mu \mathrm{g}$ of $\mathrm{E}_{2}$ as a single dose in an injection volume of $0.1 \mathrm{ml}$ of propylene glycol. Other rats received a single s.c. injection of $100 \mu \mathrm{g}$ of $2 \mathrm{ME}$ (Steraloids, Newport, RI, USA) in an injection volume of $0.1 \mathrm{ml}$ of propylene glycol. Control rats received propylene glycol alone.

\section{Local administration of drugs}

Unmated and mated rats were injected in the ovarian bursa (i.b.) with one of the drugs described below. Control rats received the appropriate vehicle only. Forskolin (7 $\beta$-acetoxy-8, 13-epoxy-1,6ß,9-trihydroxy-labd-14-ene-11-one; Sigma Chemical) and dbcAMP (Sigma Chemical) were used to determine whether $E_{2}$ non-genomic signaling pathway is functional downstream of CAMP generation in mated rats using acceleration of ovum transport as end point response. Forskolin, $20 \mu \mathrm{g}$, dissolved in $4 \mu \mathrm{l}$ of $25 \%$ ethanol and dbcAMP, $400 \mu \mathrm{g}$, dissolved in saline were injected i.b. in unmated and mated rats. Previously, we had determined that this dose of forskolin applied i.b. accelerates ovum transport in unmated rats (Orihuela et al. 2003). ICI 182780 (kindly donated by W Elger, Entech, Jena, Germany) was used to block the ER, and to determine whether ER is required for increased expression of STAR induced by $E_{2}$. ICI 182780 , $25 \mu \mathrm{g}$, dissolved in $4 \mu \mathrm{l}$ of $25 \%$ DMSO was injected i.b. in unmated rats immediately before injecting $10 \mu \mathrm{g}$ of $E_{2}$ s.c. This dose of ICI 182780 completely blocks the effect of $E_{2}$ on egg transport (Orihuela et al. 2003). SQ 22536, an adenylyl cyclase inhibitor, was used to determine whether the $E_{2}$ non-genomic signaling pathway is responsible for increasing STAR protein level in unmated rats. SQ 22536,
$30 \mu \mathrm{g}$, dissolved in saline was injected i.b. in unmated rats immediately before injecting $10 \mu \mathrm{g}$ of $\mathrm{E}_{2}$ s.c. OR 486 (Tocris, Langford, UK) was used to inhibit COMT activity in the oviduct, and to determine whether local conversion of $\mathrm{E}_{2}$ to $\mathrm{MEs}$ is important to increase STAR protein level in unmated rats. OR 486, $125 \mu \mathrm{g}$, dissolved in $4 \mu \mathrm{l}$ of $25 \%$ ethanol was injected i.b. in unmated rats immediately before injecting $10 \mu \mathrm{g}$ of $\mathrm{E}_{2}$ s.c.

Once oviducts were removed, all manipulations were done on an ice-cooled plate.

\section{Measurement of cAMP levels}

Three hours after $E_{2}$ or vehicle injection, unmated $(N=6)$ or mated $(N=6)$ rats were killed and their oviducts were flushed individually. Oviducts in groups of two (one rat) were homogenized in $0.5 \mathrm{ml}$ of ice-cold $10 \%(\mathrm{v} / \mathrm{v})$ trichloroacetic acid and centrifuged for $15 \mathrm{~min}$ at $2200 \mathrm{~g}$ at $4{ }^{\circ} \mathrm{C}$. The pellet was discarded, and the supernatant was washed four times with five volumes of water-saturated diethyl ether. The upper layer was discarded after each wash. Following the last wash, the aqueous extract was dried under a stream of nitrogen at $60{ }^{\circ} \mathrm{C}$. Levels of cAMP in dried extracts were determined using Biotrak cAMP enzyme immunoassay system (catalog no. RPN 225; Amersham Pharmacia Biotech, Piscataway, NJ, USA). This kit is based on the competition between unlabeled cAMP and a fixed quantity of peroxidase-labeled CAMP for a limited number of binding sites on a cAMPspecific antibody. This allows for the construction of a standard curve and the measurement of cAMP levels in unknown samples. Color was developed with 3,3',5,5'tetramethylbenzidine/hydrogen peroxide as a substrate. Optical density was read at $630 \mathrm{~nm}$ with a microplate reader (BIO-TEK Instruments, Winooski, VT, USA). Previously, we had determined that $E_{2}$ increases CAMP levels at this time in the oviduct of unmated rats through a non-genomic signaling pathway (Orihuela et al. 2006; and P Orihuela 2006, unpublished observations).

\section{Animal surgery}

Intrabursal administration, which minimizes the dose needed to affect the oviduct, avoiding systemic effects, was performed on unmated and mated rats at $1200 \mathrm{~h}$ as described by Orihuela \& Croxatto (2001). Briefly, the oviduct and ovary were exposed through flank incisions made under anesthesia, and using a surgical microscope (OPMI 6-SDFC; Zeiss, Oberkochen, Germany), the drugs or vehicle alone was injected into the periovarian sac using a Hamilton syringe (Hamilton Co., Reno, $N V$, USA), and the injection site in the bursa was immediately sealed with an electric coagulator (Codman CMC-1; Codman and Shurleff Inc., Randolph, MA, USA). The organs were returned to the peritoneal cavity, and the muscles and skin were sutured. Since ovulation was completed at this time point, this treatment did not affect the number of oocytes that ovulated. Furthermore, we had previously demonstrated that drugs that are administered i.b. act locally on the oviduct (Orihuela \& Croxatto 2001, Orihuela et al. 2006). 


\section{Assessment of egg transport}

Animals were killed $24 \mathrm{~h}$ after treatment, and their oviducts were flushed individually with saline. Each flushing was examined under low-power magnification $(25 \times)$. The number of eggs in both oviducts was recorded as a single datum. We had previously determined that the recovery of eggs using this method is close to $100 \%$ by comparing the average number of eggs obtained from oviducts with this technique with the number of implanted embryos on day 12 of pregnancy (Ortiz et al. 1979). Attempts to recover eggs from the uterus and vagina with or without placing ligatures in the uterine horns have shown that the reduction in the number of oviductal oocytes following treatment with $\mathrm{E}_{2}$ corresponds to premature transport to the uterus (Ortiz et al. 1979). Thus, we refer to this phenomenon as $E_{2}$-induced acceleration of oviductal transport.

\section{Oviduct collection and microarray analysis}

Unmated $(N=10)$ and mated $(N=10)$ rats were injected s.c. with $10 \mu \mathrm{g}$ of $\mathrm{E}_{2}(N=5)$ or vehicle $(N=5)$ at noon, and $3 \mathrm{~h}$ later, they were killed and their oviducts were collected and flushed. Total oviductal RNA was isolated from each rat using Trizol reagent (Invitrogen), and equivalent quantities were mixed to generate four pools: unmated group treated with $E_{2}$ (unmated group $\mathrm{E}_{2}$ ), unmated group treated with vehicle (unmated group vehicle), mated group treated with $E_{2}$ (mated group $E_{2}$ ), and mated group treated with vehicle (mated group vehicle). RNA probes prepared from each group were hybridized by Genome Explorations Inc. to the Rat Genome 2302.0 chips (Affymetrix GeneChip System; Affymetrix, Santa Clara, CA, USA) according to the manufacturer's instructions. The transcriptome profile of the genes that were increased or decreased by $E_{2}$ in the unmated group was compared to that of those that were increased or decreased by $E_{2}$ in the mated group.

\section{Real-time PCR}

In order to determine the response of Star and $C k b$ RNA expression in the oviduct to $E_{2}$, unmated and mated rats were injected s.c. with $10 \mu \mathrm{g}$ of $E_{2}$ or vehicle, and they were killed at various time intervals and their oviducts were collected and flushed. Total oviductal RNA was isolated from each rat using RNAsolv (Omega Bio-Tek, Norcross, GA, USA), and $1 \mu \mathrm{g}$ of total RNA of each sample (two oviducts from one rat) was treated with DNase I (amplification grade; Invitrogen). The single-strand cDNA was synthesized by reverse transcription using the Superscript III Reverse Transcriptase First Strand System for RT-PCR (Invitrogen) according to the manufacturer's protocol. The Light Cycler instrument (Roche Diagnostics) was used to quantify the relative gene expression of Star and $C k b$ in the oviducts of unmated and mated rats treated with $E_{2}$ or vehicle; Gapdh was chosen as the housekeeping gene for loading control. The SYBR Green I double-strand DNA binding dye from QuantiTec Real-Time RT-PCR kit (Qiagen) was the reagent of choice for these assays. The following primers were used: for Star, sense $5^{\prime}$-CTG CTA GAC CAG CCC ATG GAC-3' and antisense $5^{\prime}$-TGA TTT CCT TGA CAT TTG GGT TCC-3'; for $C k b$, sense $5^{\prime}$-AAG CTG GCA GTA GAA GCC CT-3' and antisense $5^{\prime}$-TTG TCG AAG AGG AAG TGG TC-3'; and for Gapdh, sense 5'-ACC ACA GTC CAT GCC ATC AC-3' and antisense $5^{\prime}$-TCC ACC ACC CTG TTG CTG TA-3'. All real-time PCR assays were performed in duplicate. The thermal cycling conditions included an initial activation step at $95^{\circ} \mathrm{C}$ for $25 \mathrm{~min}$, followed by 40 cycles of $95{ }^{\circ} \mathrm{C}$ for $15 \mathrm{~s}, 59{ }^{\circ} \mathrm{C}$ for $30 \mathrm{~s}$, and $72{ }^{\circ} \mathrm{C}$ for $30 \mathrm{~s}$, with an ultimate melting cycle $\left(95-60^{\circ} \mathrm{C}\right)$. In order to verify the specificity of each product, amplified products were subjected to melting curve analysis as well as to electrophoresis, and product sequencing was performed using an ABI Prism 310 sequencer. The expression of Star was determined using the equation: $Y=2^{-\Delta C_{\mathrm{p}}}$, where $Y$ is the relative expression, $C_{\mathrm{p}}$ (crossing point) is the cycle in the amplification reaction in which fluorescence begins to expand exponentially above the background baseline, and $-\Delta C_{\mathrm{p}}$ is the result of subtracting the $C_{p}$ value of Star from the $C_{p}$ value of Gapdh for each sample. To simplify the presentation of the data, the relative expression values were multiplied by $10^{3}$ (Livak \& Schmittgen 2001).

\section{Immunoblotting}

Oviducts obtained from unmated and mated rats $(N=3$ animals for each described experiment) were flushed, and their total proteins were isolated as described by Irusta et al. (2003). Briefly, oviducts were lysed in lysis buffer $\left(20 / \mathrm{ml}^{3}\right.$ Tris$\mathrm{HCl}, \mathrm{pH} 8.0,137 / \mathrm{ml}^{3} \mathrm{NaCl}, 1 \%$ Nonidet P-40, and $10 \%$ glycerol) supplemented with a protease inhibitor cocktail (Complete; Roche). The lysate was centrifuged at $4{ }^{\circ} \mathrm{C}$ for $10 \mathrm{~min}$ at $10000 \mathrm{~g}$, and the pellet was discarded. Protein concentrations in the supernatant were measured by the Bradford assay (Bio-Rad). After boiling for $5 \mathrm{~min}$, proteins $(20 \mu \mathrm{g})$ were separated on $15 \%$ SDS-PAGE slab gels in a Mini PROTEAN electrophoretic chamber (Bio-Rad). Proteins resolved in the gels were electroblotted onto nitrocellulose membranes (Bio-Rad). The membranes were blocked for $3 \mathrm{~h}$ in TTBS (100/ml $\mathrm{ml}^{3}$ Tris- $\mathrm{HCl}(\mathrm{pH} 7.5), 150 / \mathrm{ml}^{3} \mathrm{NaCl}, 0.05 \%(\mathrm{v} / \mathrm{v})$ Tween-20) that contained 5\% non-fat dry milk, and were incubated overnight with rabbit anti-STAR (kindly donated by Dr Douglas Stocco, Texas University) or mouse anti- $\alpha$-tubulin antibody ((T5168) Sigma Chemical) at 1:1500 or 1:5000 dilution respectively. The blots were rinsed five times for 5 min each in TBS $\left(100 / \mathrm{ml}^{3}\right.$ Tris- $\mathrm{HCl}, \mathrm{pH} 7.5$, and $150 / \mathrm{ml}^{3}$ $\mathrm{NaCl}$ ) and were incubated for $1 \mathrm{~h}$ in TTBS that contained HRP-conjugated goat anti-rabbit or anti-mouse IgG (1:5000 dilution; Chemicon, Billerica, MA, USA). HRP activity was detected by ECL using Western Lightning Chemiluminescence Reagent Plus (PerkinElmer Life Sciences, Boston, MA, USA). Oviductal samples without anti-STAR or antitubulin antibody were included as negative controls.

\section{Immunohistochemistry}

Oviducts from unmated rats treated s.c. with $E_{2}(N=3$ animals) and sacrificed $4.5 \mathrm{~h}$ later were fixed in cold $4 \%$ paraformaldehyde in PBS, $\mathrm{pH} 7.4-7.6$, for $2 \mathrm{~h}$, and then a sequential transfer to $10 \% \mathrm{w} / \mathrm{v}$ sucrose in PBS for $60 \mathrm{~min}$ at $4{ }^{\circ} \mathrm{C}$ and $30 \% \mathrm{w} / \mathrm{v}$ sucrose in PBS at $4{ }^{\circ} \mathrm{C}$ overnight was done.

Cryostat sections, 4-6 $\mu \mathrm{m}$ thick, were placed onto gelatincoated slides and were blocked with $1 \%$ PBS-BSA for 120 min, 
and then incubated with 1:100 anti-STAR antibody in 1\% PBSBSA in a humidified chamber overnight. Three PBS rinses were followed by 60 -min incubation at room temperature with secondary antibody biotin-conjugated anti-rabbit IgG (Biosource, Nivelles, Belgium) diluted in 1\% PBS-BSA. After three PBS rinses, the slides were incubated with avidin-FITC (Sigma) that was diluted 1:5000 for $60 \mathrm{~min}$ at room temperature. Samples were subsequently washed with PBS, counterstained with $1 \mu \mathrm{g} / \mathrm{ml}$ propidium iodide, and mounted in DABCO (Sigma). As a negative control, the primary antibody was replaced by preimmune serum. The resulting staining was evaluated using a Zeiss confocal laser scanning microscope.

\section{Statistical analyses}

The results are presented as mean \pm S.E.M. Overall analysis was carried out using the Kruskal-Wallis test, followed by the Mann-Whitney test for pairwise comparisons when overall significance was detected. The actual $N$ value in the experiments that were performed to determine the effects of drugs on oviductal egg transport is the total number of rats used in each experimental group.

\section{Declaration of interest}

The authors declare that there is no conflict of interest that could be perceived as prejudicing the impartiality of the research reported.

\section{Funding}

This work was supported by FONDECYT (grant numbers 8980008, 1030315, 1080523, and 1040804), PROGRESAR (grant number PRE 004/2003), and Proyecto BASAL FBO-07.

\section{Acknowledgements}

We thank Andrea Gómez, PhD, from Millenium Nucleus of Stress and Addiction in Chile (NEDA) for figure design advice.

\section{References}

Abudara V, Garcés G \& Sáez JC 1999 Cells of the carotid body express connexin 43 which is up-regulated by cAMP. Brain Research 849 25-33.

Ardekani AM, Romanelli JC \& Mayo KE 1998 Structure of the rat inhibin and activin betaA-subunit gene and regulation in an ovarian granulosa cell line. Endocrinology 139 3271-3279.

Bhatt P, Kadam K, Saxena A \& Natraj U 2004 Fertilization, embryonic development and oviductal environment: role of estrogen induced oviductal glycoprotein. Indian Journal of Experimental Biology 42 1043-1055.

Bilezikjian LM, Corrigan AZ, Blount AL, Chen Y \& Vale WW 2001 Regulation and actions of Smad7 in the modulation of activin, inhibin, and transforming growth factor-beta signaling in anterior pituitary cells. Endocrinology 142 1065-1072.

Bjornstrom L \& Sjoberg M 2005 Mechanisms of estrogen receptor signaling: convergence of genomic and nongenomic actions on target genes. Molecular Endocrinology 19 833-842.

Blake CA, Brown LM, Duncan MW, Hunsucker SW \& Helmke SM 2005 Estrogen regulation of the rat anterior pituitary gland proteome. Experimental Biology and Medicine 230 800-807.
Brann DW, Zhang QG, Wang RM, Mahesh VB \& Vadlamudi RK 2008 PELP1 - a novel estrogen receptor-interacting protein. Molecular and Cellular Endocrinology 290 2-7.

Buhi WC 2002 Characterization and biological roles of oviductspecific, oestrogen dependent glycoprotein. Reproduction 123 355-362.

Carlsson B, Hillensjo T, Nilsson A, Tornell J \& Billig H 1993 Expression of insulin-like growth factor-I (IGF-I) in the rat fallopian tube: possible autocrine and paracrine action of fallopian tube-derived IGF-I on the fallopian tube and on the preimplantation embryo. Endocrinology 133 2031-2039.

Cheskis BJ, Greger JG, Nagpal S \& Freedman LP 2007 Signaling by estrogens. Journal of Cell Physiology 213 610-617.

Cheskis BJ, Greger J, Cooch N, McNally C, Mclarney S, Lam HS, Rutledge S, Mekonnen B, Hauze D, Nagpal S et al. 2008 MNAR plays an important role in ERa activation of Src/MAPK and PI3K/Akt signaling pathways. Steroids 73 901-905.

Clark BJ, Ranganathan V \& Combs R 2001 Steroidogenic acute regulatory protein expression is dependent upon post-translational effects of cAMPdependent protein kinase A. Molecular and Cellular Endocrinology 173 183-192.

Croxatto HB 1996 Gamete transport. In Reproductive Endocrinology, Surgery and Technology, edn 3, pp 385-402. Eds EY Adashi, JA Rock \& Z Rosenwaks. Philadelphia: Lippincott-Raven Publishers.

Croxatto HB 2002 Physiology of gamete and embryo transport through the fallopian tube. Reproductive Biomedicine Online 4 160-169.

Croxatto HB, Ortiz ME, Forcelledo ML, Fuentealba B, Noé G, Moore G, Moran F \& Cárdenas H 1991 Hormonal control of ovum transport through the rat oviduct. Archivos de Biología y Medicina Experimentales 24 403-410.

Forcelledo ML, De la Cerda ML \& Croxatto HB 1986 Effectiveness of different estrogen pulses in plasma for accelerating ovum transport and their relation to estradiol levels in the rat oviduct. Endocrinology 119 1189-1194.

Gómez-Sánchez EP, Ganjam V, Chen YJ, Liu Y, Zhou MY, Toroslu C, Romero DG, Hughson MD, de Rodriguez A \& Gómez-Sánchez CE 2003 Regulation of 11 beta-hydroxysteroid dehydrogenase enzymes in the rat kidney by estradiol. American Journal of Physiology. Endocrinology and Metabolism 285 E272-E279.

González-Arenas A, Villamar-Cruz O, Guerra-Araiza C \& CamachoArroyo I 2003 Regulation of progesterone receptor isoforms expression by sex steroids in the rat lung. Journal of Steroid Biochemistry and Molecular Biology 85 25-31.

Hermoso M, Sáez JC \& Villalón M 1997 Identification of gap junctions in the oviduct and regulation of connexins during development and by sexual hormones. European Journal of Cell Biology 74 1-9.

Ikeda Y, Nagai A, Ikeda MA \& Hayashi S 2001 Neonatal estrogen exposure inhibits steroidogenesis in the developing rat ovary. Developmental Dynamics 221 443-453.

Irusta G, Parborell F, Peluffo M, Manna PR, Gonzalez-Calvar SI, Calandra R, Stocco DM \& Tesone M 2003 Steroidogenic acute regulatory protein in ovarian follicles of gonadotropin-stimulated rats is regulated by a gonadotropin-releasing hormone agonist. Biology of Reproduction 68 1577-1583.

Jansen RP 1984 Endocrine response in the fallopian tube. Endocrine Reviews 5 525-551.

Livak KJ \& Schmittgen TD 2001 Analysis of relative gene expression data using real-time quantitative PCR and the 2(T) (-Delta Delta C) method. Methods 25 402-408.

Mathieu CL, Mills SE, Burnett SH, Cloney DL, Bruns DE \& Bruns ME 1989 The presence and estrogen control of immunoreactive calbindin-D9k in the fallopian tube of the rat. Endocrinology 125 2745-2750.

O'Lone R, Frith MC, Karlsson EK \& Hansen U 2004 Genomic targets of nuclear estrogen receptors. Molecular Endocrinology $\mathbf{1 8}$ 1859-1875.

Orihuela PA \& Croxatto HB 2001 Acceleration of oviductal transport of oocytes induced by estradiol in cycling rats is mediated by nongenomic stimulation of protein phosphorylation in the oviduct. Biology of Reproduction 65 1238-1245.

Orihuela PA, Ríos M \& Croxatto HB 2001 Disparate effects of estradiol on egg transport and oviductal protein synthesis in mated and unmated rats. Biology of Reproduction 65 1232-1237. 
Orihuela PA, Parada-Bustamante A, Cortés PP, Gatica C \& Croxatto HB 2003 Estrogen receptor, cyclic adenosine monophosphate, and protein kinase a are involved in the nongenomic pathway by which estradiol accelerates oviductal oocyte transport in cyclic rats. Biology of Reproduction 68 1225-1231.

Orihuela PA, Zuñiga LM, Rios M, Llados C, Sierralta W \& Croxatto HB 2004 Estrogen receptors in the rat oviduct. Molecular Biology of the Cell 15 265A.

Orihuela PA, Parada-Bustamante A, Zúñiga LM \& Croxatto HB 2006 Inositol triphosphate participates in an oestradiol nongenomic signalling pathway involved in accelerated oviductal transport in cycling rats. Journal of Endocrinology 188 579-588.

Ortiz ME, Villalón M \& Croxatto HB 1979 Ovum transport and fertility following post-ovulatory treatment with estradiol in rats. Biology of Reproduction 21 1163-1167.

Parada-Bustamante A, Orihuela PA \& Croxatto HB 2003 Effect of intrauterine insemination with spermatozoa or foreign protein on the mechanism of action of oestradiol in the rat oviduct. Reproduction $\mathbf{1 2 5}$ 677-682.

Parada-Bustamante A, Orihuela PA, Ríos M, Navarrete-Gómez PA, Cuevas CA, Velásquez LA, Villalón MJ \& Croxatto HB 2007 Catechol$O$-methyltransferase and methoxyestradiols participate in the intraoviductal nongenomic pathway through which estradiol accelerates egg transport in cycling rats. Biology of Reproduction 77 934-941.

Peñarroja-Matutano C, Parada-Bustamante A, Orihuela PA, Ríos M, Velásquez LA \& Croxatto HB 2007 Genital sensory stimulation shifts estradiol intraoviductal signaling from nongenomic to genomic pathways, independently from prolactin surges. Biological Research $\mathbf{4 0}$ 213-222.

Pérez Martínez S, Hermoso $M$, Farina $M$, Ribeiro $M L$, Rapanelli $M$, Espinosa M, Villalón M \& Franchi A 2006 17ß-Estradiol upregulates COX-2 in the rat oviduct. Prostaglandins \& Other Lipid Mediators 80 155-164.

Priyadarsana M, Wijayagunawardane B \& Miyamoto A 2004 Endothelin-1 system in the bovine oviduct: a regulator of local contraction and gamete transport. Journal of Cardiovascular Pharmacology $\mathbf{4 4}$ S248-S251.
Ríos M, Orihuela PA \& Croxatto HB 1997 Intraoviductal administration of ribonucleic acid from estrogen-treated rats mimics the effect of estrogen on ovum transport. Biology of Reproduction $\mathbf{5 6}$ 279-283.

Ríos M, Hermoso M, Sánchez TM, Croxatto HB \& Villalón MJ 2007 Effect of oestradiol and progesterone on the instant and directional velocity of microsphere movements in the rat oviduct: gap junctions mediate the kinetic effect of oestradiol. Reproduction, Fertility, and Development 19 634-640.

Scott RE, Wu-Peng XS, Kaplitt MG \& Pfaff DW 2003 Gene transfer and in vivo promoter analysis of the rat progesterone receptor using a herpes simplex virus viral vector. Brain Research. Molecular Brain Research 114 91-100.

Smith MS, Freeman ME \& Neill JD 1975 The control of progesterone secretion during the estrous cycle and early pseudopregnancy in the rat: prolactin, gonadotropin and steroid levels associated with rescue of the corpus luteum of pseudopregnancy. Endocrinology 96 219-226.

Stocco DM \& Clark BJ 1996 Regulation of the acute production of steroids in steroidogenic cells. Endocrine Reviews 17 221-244.

Stocco DM, Wang X, Jo Y \& Manna PR 2005 Multiple signaling pathways regulating steroidogenesis and steroidogenic acute regulatory protein expression: more complicated than we thought. Molecular Endocrinology 19 2647-2659.

Turner CD 1961 Endocrinology of the ovary. In General Endocrinology, edn 3, pp 365-409. Ed. CD Turner. Philadelphia: WB Saunders Company.

Villalón M \& Verdugo P 1982 Hormonal regulation of ciliary function in the oviduct: the effect of beta-adrenergic agonists. Progress in Clinical and Biological Research 80 59-65.

Ye F, Florian M, Magder SA \& Hussain SN 2004 Regulation of angiopoietin and Tie-2 receptor expression in non-reproductive tissues by estrogen. Steroids 67 305-310.

Received 29 May 2009

First decision 24 August 2009

Revised manuscript received 10 November 2009

Accepted 23 December 2009 